\title{
PENENTUAN RASIO BAHAN SAMPAH ORGANIK OPTIMUM TERHADAP KINERJA COMPOST SOLID PHASE MICROBIAL FUEL CELLS (CSMFCs)
}

\author{
Meishinta Ariyanti ${ }^{1, *}$, Ganjar Samudro', Dwi Siwi Handayani ${ }^{1}$ \\ 1) Departemen Teknik Lingkungan, Fakultas Teknik, Universitas Diponegoro Jl. Prof. H. \\ Sudarto, SH Tembalang, Semarang, Indonesia 50275 \\ e-mail: meishinta.ariyanti@gmail.com
}

\begin{abstract}
Abstrak
Compost Solid Phase Microbial Fuel Cells (CSMFCs) merupakan teknologi pengomposan yang diintegrasikan dengan sistemMFCs untuk menghasilkan kompos dan produksi biolistrik dari sampah padat organik. Penelitian ini bertujuan untuk meningkatkan kinerja CSMFCs melalui penerapan perlakuan optimaldari penelitian terdahulu seperti, kadar air $60 \%$, volume sampah 2/3 reaktor, dan penambahan bioaktivator.CSMFCs dalam penelitian ini dilakukan dalam kondisi batchmenggunakan reaktor tipe single chamber dan dual anode graphene.Sampah daun dan sampah sisa makanan digunakan sebagai substratdalam studi ini. Bahan sampah tersebut divariasikan berdasarkan rasio bahan (sampah daun: sampah sisa makanan)yaitu 100:0, 0:100, dan 50:50. Hasil penelitian inimenunjukan kinerja CSMFCs yang optimumterdapat pada variasi sampah campuran keduanya dengan rasio bahan50:50. Variasi ini dapat menghasilkan kompos yang baik, yaitu memenuhi SNI 19-7030-2004, serta produksi listrik yang cukup tinggi yaitu power density $41,6 \mathrm{~mW} / \mathrm{m}^{2}$, coulombic efficiency $0,647 \%$ dan energy efficiency $0,0127 \%$.
\end{abstract}

Kata Kunci: bahan sampah, kinerja CSMFCs, pengomposan, biolistrik

\begin{abstract}
Compost Solid Phase Microbial Fuel Cells (CSMFCs) are composting technologythatintegrated with the MFCssystem to produce compost and generatebioelectricity using solid organicwaste. This study tried to enhance CSMFCsperformance by the application of optimum treatment from the previous research, used moisture content of $60 \%, 2 / 3$ waste volume of reactor volume, and the addition of bioactivator. In this study, CSMFCs operated under batch conditionsusingsingle chamber reactor and dual anode graphene. Leaf waste and food waste were used as substratewithin CSMFCs. The waste materialsvaried based on the material ratio (leaf waste:food waste) are 100:0, 0:100, and 50:50. The resultshowedthat theCSMFCs performance was optimum in mixed waste material with material ratio of 50:50. This variation produced great compost which accordance toSNI 19-7030-2004, and generated good electricity for power density $41.6 \mathrm{~mW} / \mathrm{m}^{2}$, coulombic efficiency $0.647 \%$ and energy efficiency $0.0127 \%$.
\end{abstract}

Keywords: waste material, CSMFCs performance, composting, bioelectricity

\section{Pendahuluan}

Sampah merupakan sisa kegiatan manusia sehari-hari dan/atau proses alam yang berbentuk padat (Undang-Undang RI Nomor 18, 2008). Sampah dapat dibedakan menjadi organik dan anorganik.Berdasarkan analisis karakteristik limbah padat dari banyak negara berkembang, ditemukan bahwa sebagian besar (lebih dari $80 \%$ ) dari total limbah padat terdiri dari sampah organik, biasanya kurang mendapatkan banyak perhatian untuk diolah atau didaur ulang (Moqsud et al., 2008).

Dalam pengembangan sistem teknologi pengolahan sampah, muncul teknologi alternatif yang dapat diaplikasikan pada pengomposan menjadi sumber energi bahan bakar bernama Compost Solid Phase Microbial Fuel Cells (Wang et al., 
2013).CSMFCs merupakan salah satu teknologi MFC dengan substrat berupa limbah organik padat seperti sampah kebun, sampah daun, dan sampah sisa makanan, tujuan dari CSMFCs dapat menghasilkan energi listrik dari pengomposan.Berdasarkan penelitian Logrono, et al. (2015), yang menggunakan campuran substrat sampah organik dengan tanah pada MFC berbahan padatan tipe single chamber untuk menghasilkan bioelectricity sekaligus biotransformasi limbah organik. Nilai voltase yang dihasilkanpada MFCs, nilai tertinggi keluaran voltase sebesar $330 \mathrm{mV}$ dan power density sekitar $2,8 \mathrm{~mW} / \mathrm{m}^{2}$.SMFCyang berisi perpaduan $75: 25$ buah dan sayuran.

Kelebihan CSMFCs ini adalah penurunan bahan organik yang tinggi, hasil lumpur lebih sedikit dan selanjutnya dapatdihasilkan menjadi kompos, pupuk cair, biogas, dan energi listrik secara langsung.Beberapa penelitian telah menerapkan CSMFCs sebagai teknologi pemroses sampah maupun bahan padat lainnya. Penelitian Wang et al. (2015), menggunakan campuran sampah organik domestik seperti ampas kedelai, ampas kopi, dedaun, dan sekam padi untuk mengobservasi performa listrik CSMFCs. Rasio $\mathrm{C} / \mathrm{N}$ awal 31,4 dengan kadar air $60 \%$ diperoleh power density optimal $4,6 \mathrm{~mW} / \mathrm{m}^{2}$. CSMFCs memang masih dalam tahap pengembangan namun memiliki potensi besar dari segi inovasi dan dapat menjadi energi alternatif untuk menggantikan energi fosil (Kothapalli, 2013).Oleh karena itu,penelitian ini dilakukan dengan tujuan untuk meningkatkan kinerja CSMFCsberdasarkanvariasi rasio bahan sampah.

\section{Metodologi Penelitian}

Penelitian ini menggunakan metode eksperimental yaitu dilakukan melalui observasi.Substrat yang digunakan berupa sampah organik yaitu sampah daun dari area Universitas Diponegoro dan sampah sisa makanan diperoleh dari rumah makan area Tembalang.Pemilihan substrat berdasarkan banyaknya sampah yang dihasilkan dan memiliki kandungan substrat organik yang tinggi.Sebelum dikomposkan, sampah yang berukuran besar akandicacah terlebih dahulu supaya proses degradasi dapat lebih cepat.

Reaktor lab-scale yang digunakan dengan tipe single chamber yang terdiri dari dual anoda dan satu katoda.Penelitian di lakukan secara destruktif dengan variabel yang telah ditentukan serta reaktor dikondisikan batch selama 23 hari.Tidak dilakukan penambahan substrat sampah dan sumber bakteri pada saat pengomposan berlangsung. Reaktor yang digunakan berukuran 2,5 liter. Desain lab-scale tersebut dipilih untuk memudahkan dalam observasi penelitian.Elektroda yang digunakan berasal dari graphene handmade.Penggunaan graphene sebagai elektrodadapat mengurangi kehilanggan potensial listrik sehingga memperkuat kinerja MFC.Serta dapat dibuat dalam suhu ruang menggunakan larutan kimia sederhana yang terjangkau.Pembuatan graphene diawali dengan aktivasi batang aluminium dengan larutan $\mathrm{HCl} 1 \mathrm{Mdan} \mathrm{NaOH} 1 \mathrm{M}$. Setelah itu, plat dilapisi dengan serbuk karbon dan cairan polyurethane yang dicampurkan dengan perbandingan 1:2. Lalu serbuk karbon murni ditaburkan lagi di atas plat aluminium dan didiamkan hingga kering. Kemudian seluruh bagian plat yang telah tertutupi serbuk karbon diolesi dengan larutan asam fosfat $85 \%$ dengan tujuan agar butir serbuk saling menempel dengan plat aluminium. Elektroda yang digunakan berukuran $2,5 \mathrm{~cm} \times 10$ $\mathrm{cm}$. Kompartemen katoda dikondisikan kontak dengan udara - air chatode. Skema reaktor terdapat pada Gambar 1.

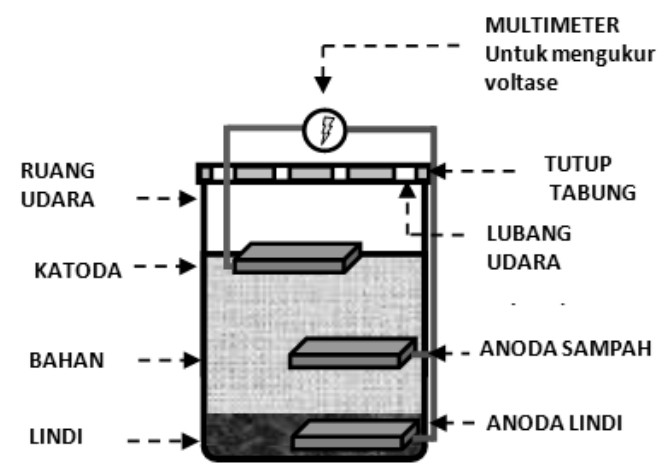

Gambar 1.Skema Reaktor CSMFCs

Variabel bebas pada penelitian ini adalah rasio bahan sampah.Serta variabel terikatnyayaitu parameter pengomposan (Suhu, pH, Kadar C-Organik, N-Total, Rasio $\mathrm{C} / \mathrm{N}$, P-Total dan K-Total) serta parameter listrik (PD, CE dan EE).Data untuk analisis produksi listrik diperoleh dari hasil pengukuran voltase dan hambatan dengan menggunakan digital multimeter DT-9205A dan hasil perhitungan arus. Nilai kuat arus dan voltase yang diperoleh kemudian dikonversi ke power density, PD $\left(\mathrm{mW} / \mathrm{m}^{2}\right)$ sesuai dengan rumus (Logan, 2008) di bawah ini :

$$
\mathrm{P}_{\mathrm{D}}=\frac{\mathrm{VxI}}{\mathrm{A}}
$$


dimana, I (mA) adalah arus listrik, $\mathrm{V}$ (volt) adalah tegangan/ beda potensial dan $\mathrm{A}\left(\mathrm{m}^{2}\right)$ adalah luas permukaan yang digunakan mikroorganisme bertumbuh di anoda graphene.

Kinerja CSMFCsdalam produksi listrikjuga dievaluasi berdasarkan efisiensinya melalui coulombic efficiency, $\mathrm{CE}(\%)$ dan energy efficiency, EE (\%). Nilai CE dikalkulasikan menggunakan persamaan (Logan, 2008) berikut :

$$
\mathrm{CE}=\frac{\mathrm{M}_{\mathrm{S}} \int \mathrm{Idt}}{\mathrm{Fb}_{\mathrm{es}} \mathrm{V}_{\mathrm{an}} \Delta \mathrm{COD}} \times 100 \%
$$

dimana $\mathrm{M}_{\mathrm{s}}$ adalah berat molekul substrat, I adalah arus listrik pada selang waktu dt, $F$ adalah konstanta faraday (96485 Coulomb), bes adalah mol elektron yang dihasilkan selama proses oksidasi beban organik dalam bentuk kadar COD. $\mathrm{M}_{\mathrm{s}}$ adalah berat molekul oksigen yaitu 32 dan elektron yang dihasilkan per mol oksigen, bes adalah 4), $v_{a n}$ adalah volume substrat di anoda dan $\triangle \mathrm{COD}$ adalah konsentrasi COD susbtrat (Logan, 2008).
Nilai energy efficiency (EE) dikalkulasikan dengan menggunakan persamaan (Liu et al., 2005) berikut :

$$
\mathrm{EE}=\frac{\mathrm{M}_{\mathrm{i}} \int_{0}^{\mathrm{tb}} \mathrm{Pdt}}{\Delta \mathrm{H} \mathrm{S}_{\mathrm{i}} \mathrm{v}}
$$

dimana, $\mathrm{P}$ adalah daya (watt), tb adalah waktu untuk satu siklus batch, $\Delta \mathrm{H}$ adalah perubahan entalpi reaksi $(\mathrm{J} / \mathrm{mol}), \mathrm{Si}$ adalah konsentrasi substrat $(\mathrm{g} / \mathrm{L}), \mathrm{v}$ adalah volume liquid dalam kompartemen anoda (L), dan Mi adalah berat molekul substrat $(\mathrm{g} / \mathrm{mol})$.

Perlakuan volume sampah $2 / 3$ dari volume reaktor, penambahan bioaktivator EM-4 dan kadar air $60 \%$ untuk keseluruhan reaktor, sebagai variabel kontrolkarena mempengaruhi variabel bebas dan variabel terikat. Variasi reaktor pada proses runningbatch terdapat pada Tabel 1, dapat dilihat bahwa jenis reaktor dibedakan berdasarkan variasi rasio bahan sampah.Variasi rasio bahan sampah berdasarkan penelitian Logrono et al. (2015), untuk mengetahui variasi rasio bahan sampah yang paling menguntungkan untuk menghasilkan kompos dan produksi listrik.

Tabel 1.Variasi Reaktor Berdasarkan Rasio Bahan Sampah

\begin{tabular}{lcccc}
\hline Bahan Sampah & $\begin{array}{c}\text { Rasio } \\
\text { Daun : Makanan }\end{array}$ & Kadar Air & Proses & Kode Reaktor \\
\hline Daun & $100: 0$ & $60 \%$ & Batch & D60 \\
Makanan & $0: 100$ & $60 \%$ & Batch & M60 \\
Campuran & $50: 50$ & $60 \%$ & Batch & C60 \\
\hline
\end{tabular}

\section{Hasil dan Pembahasan}

Proses running dilakukan selama 23 hari terhitung sejak tanggal 20 Mei 2018 hingga 12 Juni 2018 dengan 8 kali pengambilan data pada hari ke-0, 1, 3, 5, 10, 15, 20, dan 23. Hari pengambilan sampel tersebut didasarkan pada penelitian Samudro, et al. (2017), dengan tujuan data yang diharapkan dapat menggambarkan kurva pertumbuhan mikroorganisme pada umumnya, yakni lag phase, exponential phase, stationery phase dan death phase.

\section{Produksi Kompos}

\section{$\underline{\text { Suhu }}$}

Peningkatan suhu kompos secara drastis pada hari ke-3.Hal ini terjadi karena terdapat aktivitas mikroba menguraikan sampah organik.Suhu puncak pengomposan yaitu, $38^{\circ} \mathrm{C}$ pada sampah makanan, $36^{\circ} \mathrm{C}$ pada sampah campuran dan $35^{\circ} \mathrm{C}$ pada sampah daun.Pada tumpukan sampah makanan memiliki tingkat porositas yang rendah daripada sampah daun sehingga kemampuan dalam mempertahankan panas lebih tinggi. Porositas kompos adalah celah rongga di antara tumpukan kompos (Widarti dkk., 2015). Hal ini terjadi akibat suhu sulit menguap keluar karena sedikitnya rongga yang ada.Peningkatan suhu terjadi karena adanya aktivitas bakteri dalam mendekomposisi bahan organik. Menurut Wahyono dkk (2011), semakin tinggi tumpukan sampah maka suhu yang dihasilkan semakin tinggi. Pada akhir pengomposan, suhu pada semua variasi kompos berkisar pada $27^{\circ} \mathrm{C}$.

\section{Derajat Keasaman $(\mathrm{pH})$}

Penurunan $\mathrm{pH}$ kompos secara drastis pada hari ke-3. Selama pengomposan, $\mathrm{pH}$ pada sampah daun rentang 4,7-7,4, sampah makanan rentang $3,8-5,8$, dan sampah campuran daun-makanan rentang 4,5-6,9. Penurunan $\mathrm{pH}$ terjadi karena mikroorganisme mengubah bahan organik menjadi asam organik sehingga $\mathrm{pH}$ menurun (Sidabutar dkk., 2012). Menurut Kusuma (2012), pH 
dipengaruhi oleh adanya nitrogen dan keadaan anaerobik. Mikroorganisme tertentu akan mengubah bahan organik menjadi asam organik. Selanjutnya asam organik tersebut akan dimakan oleh mikroorganimse lainnya sehinggatingkat $\mathrm{pH}$ naik mendekati netral. Hasil akhir $\mathrm{pH}$ pengomposan, sampah makanan tidak memenuhi SNI 19-7030-2004, dibawah rentang 6,8-7,49yaitu 5,8. Menurut Mulyani (2014), nilai pH yang rendah pada kompos tidak baik karena menyebabkan unsur hara $\mathrm{N}, \mathrm{P}, \mathrm{K}, \mathrm{Ca}, \mathrm{Mg}$ sulit terlarut sehingga sukardiserap oleh tumbuhan.

\section{Kadar C-Organik}

Kadar C-Organik awal mulai dari tertinggi ke terendah, yaitupada sampah campuran $27,64 \%$, sampah daun $26,43 \%$, dan sampah makanan $23,41 \%$. Tinggi rendahnya kandungan C-Organik awal akan mempengaruhi hasil akhir pengomposan. Hasil kadar C-Organik akhir pada sampah campuran sebesar $15,83 \%$. sampah daun sebesar $14,75 \%$, dan sampah makanan sebesar $12,57 \%$.Selama pengomposan kadar C-Organik menurun karena bahan organik yang terkandung dalam sampah dikonsumsi oleh mikroorganisme. Penurunan kadar COrganik pada seluruh variasi rasio bahan sampah terjadi karena C-Organik pada sampah digunakan oleh mikroorganisme sebagai sumber energi untuk proses metabolisme dan sebagian terurai menjadi $\mathrm{CO}_{2}$ ke udara sehingga kadarnya berkurang (Setyorini dkk., 2006). Pada akhir pengomposan semua reaktor telah memenuhi SNI 19-7030-2004 terdapat pada rentang $9,8-32 \%$.

\section{Kadar N-Total}

Berdasarkan hasil penelitian, kadar N-Total awal mulai dari tertinggi ke terendahyaitu, pada sampah makanan $0,50 \%$, sampah campuran $0,45 \%$, dan sampah daun $0,38 \%$. Selama pengomposan $\mathrm{N}$-Total mengalami peningkatan. Pada sampah daun, meningkat menjadi $0,87 \%$. Pada sampah makanan menjadi $1,58 \%$. Sedangkan pada sampah campuran meningkat menjadi 0,99\%. Penurunan inidisebabkan karena nitrogen dalam pengomposan digunakan oleh mikroorganisme untuk sintesis protein.Pada pengomposan $\mathrm{N}$-Total meningkat karenamikroorganisme mengurai protein menjadi asam amino. Proses amonifikasi menjadi ammonium kemudian menghasilkan nitrit dan nitrat dari proses oksidasi (Jannah, 2003). Nitrogen kembali tersedia apabila mikroorganisme mati dan dirombak oleh mikroorganisme lainnya (Bernal et al.,
2009). Hasil akhir pengomposan untuk semua reaktor telah memenuhi kadar $\mathrm{N}$-Total sesuai SNI 19-7030-2004 yaitu minimal 0,4\%.

\section{Rasio C/N}

Nilai rasio $\mathrm{C} / \mathrm{N}$ dapat dipengaruhi faktor jenis bahan yang akan digunakan untuk kompos (Jannah, 2003).Berdasarkan hasil penelitian rasio $\mathrm{C} / \mathrm{N}$ awal mulai tertinggi ke terendah yaitu sampah daun 70,37 , sampah campuran 61,87 dan sampah makanan 46,47. Selama pengomposan, rasio $\mathrm{C} / \mathrm{N}$ mengalami penurunan. Pada akhir pegomposan, rasio $\mathrm{C} / \mathrm{N}$ pada sampah daun sebesar 17,01, sampah campuran sebesar 15,92, dan sampah makanan memiliki nilai terendah yaitu 7,95 . Penurunan rasio $\mathrm{C} / \mathrm{N}$ terjadi akibat mikroorganisme melepas $\mathrm{CO}_{2}$ ke udara sehinggakadar C-Organik turun dan kadar $\mathrm{N}$ Total naik karena terbentuknya ammonium menjadi nitrat selama dekomposisi (Jannah, 2003). Hasil akhir pengomposan untuk reaktor M60 sebesar 7,95 tidak memenuhi Rasio C/N pada SNI 19-7030-2004 yaitu di bawah rentang 10-20.Bila rasio $\mathrm{C} / \mathrm{N}$ terlalu rendah, keberadaan senyawa karbon sebagai sumber energi yang dimanfaatkan mikroorganisme terbatas untuk mengikatnitrogen bebas.Dalam hal ini jumlah nitrogen bebas dilepaskan dalam bentuk gas $\mathrm{NH}_{3}$ dan kompos yang dihasilkan mempunyai kualitas rendah (Siswanto, 2012).

\section{Kadar P-Total}

Pada pengomposan fosfor dimanfaatkan mikroorganisme untuk pembentukan zat putih telur di tubuhnya (Suswardany, dkk., 2006).Kadar P-total awal mulai dari tertinggi ke terendah yaitu, pada sampah makanan $0,39 \%$, sampah campuran $0,31 \%$, sampah daun $0,29 \%$. Selama pengomposan kadar PTotal cenderung meningkat. Pada sampah makanan, kadar P-Total akhir sebesar $0,75 \%$. Pada sampah campuran sebesar $0,56 \%$. Serta pada sampah daun, kadar PTotal akhir pada kompos sebesar 0,50\%.Menurut Ayuningtyas (2009), penurunan P-Total disebabkan karena kadar $\mathrm{P}$ dikonsumsi oleh mikroorganisme pengurai. Kadar P-Total semakin tinggi karena bahan organikyang dikomposkan telah lapuk, mikroorganisme akan mati dan kandungan $P$ dalam mikroorganisme akan tercampur dalam bahan kompos sehingga kandungan fosfor meningkat (Nurdiansyah,2015 dalam Yulianto dkk., 2017). Kadar P-Total di semua reaktor telah sesuai SNI 19-7030-2004, yaitu melebihi P-Total minimum 0,1\%. 


\section{Kadar K-Total}

Pengomposan pada penilitian ini, kadar KTotal awal mulai dari tertinggi ke terendah yaitu, pada sampah daun 1,46\%, sampah campuran $0,99 \%$, dan sampah makanan $0,85 \%$. Saat pengomposan kadar K-Total cenderung meningkat. Pada sampah daun, kadar K-Total akhir pada kompos sebesar 2,18\%. Pada sampah makanan, kadar KTotal akhir pada kompos sebesar 1,10\%. Serta sampah campuran, kadar K-Total akhir pada kompos sebesar 2,08\%. Peningkatan ini dapat terjadi karena penguraian mikroorganisme. Kalium dalam bahan substrat dimanfaatkan oleh mikroorganisme sebagai katalisator (Walidaini dkk., 2016). Penurunan kadar K-Totalselama pengomposan terjadi karena unsur kalium dari hasil penguraian bahan organik digunakan oleh mikroorganisme (Wibawati, 2013). Semua reaktor sudah memenuhi SNI 19-7030-2004 dari awal sampai akhir pengomposan kadar K-Total lebih dari 0,2\%. Kualitas kompos dapat dilihat dari tingkat kematangan kompos sebagai syarat utama untuk dipenuhi agar dapat digunakan dengan baik di dalam tanah. Kematangan kompos dapat diukur darikadarunsur hara yang terkandung dalam kompos seperti kadar karbon organik, nitrogen total, rasio $\mathrm{C} / \mathrm{N}$, fosfor, dan kalium serta melibatkan suhu dan $\mathrm{pH}$. Penentuan kualitas kompos pada penelitian ini ditinjau dari parameter suhu, $\mathrm{pH}$ dan kadar unsur hara yang telah terpenuhi berdasarkan SNI 19-7030-2004. Kualitas kompos yang baik diperoleh reaktor D60 dan C60.Rekapitulasi hasil akhir pengomposan semua reaktor dapat dilihat pada Tabel 2 .

Tabel 2.Rekapitulasi Hasil Akhir Pengomposan

\begin{tabular}{lccccccc}
\hline \multicolumn{1}{c}{ Parameter } & $\begin{array}{c}\text { SNI } \\
\mathbf{1 9 - 7 0 3 0 - 2 0 0 4}\end{array}$ & D60 & Ket. $^{*}$ & M60 & Ket. $^{*}$ & C60 & Ket.. $^{*}$ \\
\hline Suhu $\left({ }^{\circ} \mathrm{C}\right)$ & $<30{ }^{\circ} \mathrm{C}$ & 27 & $\sqrt{ }$ & 27,5 & $\sqrt{ }$ & 27 & $\sqrt{ }$ \\
pH & $6,8-7,49$ & 7,3 & $\sqrt{ }$ & 5,8 & $\mathrm{x}$ & 6,9 & $\sqrt{ }$ \\
C-Organik (\%) & $9,8 \%-32 \%$ & 14,75 & $\sqrt{ }$ & 12,57 & $\sqrt{ }$ & 15,83 & $\sqrt{ }$ \\
N-Total (\%) & $>0,4 \%$ & 0,87 & $\sqrt{ }$ & 1,58 & $\sqrt{ }$ & 0,99 & $\sqrt{ }$ \\
Rasio C/N & $10-20$ & 17,01 & $\sqrt{ }$ & 7,95 & $\mathrm{x}$ & 15,92 & $\sqrt{ }$ \\
P-Total (\%) & $>0,1 \%$ & 0,50 & $\sqrt{ }$ & 0,75 & $\sqrt{ }$ & 0,56 & $\sqrt{ }$ \\
K-Total (\%) & $>0,2 \%$ & 2,18 & $\sqrt{ }$ & 1,10 & $\sqrt{ }$ & 2,08 & $\sqrt{ }$ \\
\hline
\end{tabular}

* Ket. $=$ Keterangan

$\checkmark=$ telah memenuhi SNI 19-7030-2004

$\mathrm{x}$ = tidak memenuhi SNI 19-7030-2004

\section{Produksi Listrik}

\section{Power Density $\left(\mathrm{mW} / \mathrm{m}^{2}\right)$}

Power density atau rapat daya adalah satuan yang digunakan untuk mengetahui daya yang dapat dihasilkan sistem MFCs.Pada umumnya, daya pada sistem MFCs yang diasumsikan dihasilkan pada suatu luas area anoda dimana reaksi biologis terjadi $\left(\mathrm{mW} / \mathrm{m}^{2}\right)$ (Logan, 2008).Pada sampah daun dihasilkan PD tertinggi pada hari ke-15 sebesar 27,2 $\mathrm{mW} / \mathrm{m}^{2}$. Sampah makanan dihasilkan PD tertinggi di hari ke-5 sebesar $70,5 \mathrm{~mW} / \mathrm{m}^{2}$. Sedangkan pada sampah campuran dihasilkan PD tertinggi pada hari ke-15 sebesar $41,6 \mathrm{~mW} / \mathrm{m}^{2}$. Grafik peningkatan dan penurunan power density dapat dilihat pada Gambar 2.Sampah makanan menghasilkan power density lebih tinggi dibandingkan dengan sampah daun.Hal ini disebabkan karena sampah daun memiliki molekul senyawa organik yang lebih kompleks misalnya selulosa. Menurut Kristin (2012), substrat yang banyak mengandung organik membantu metabolisme beragam mikroba, namun substrat sederhana lebih baik untuk menghasilkan energi listrik dalam waktu singkat. Mikroorganisme lebih mudah memanfaatkan nutrisi yang terdapat pada substrat sederhana.Berdasarkan hasil perhitungan dapat disimpulkan power density tertinggi terjadi di reaktor sampah makanan.

\section{Coulombic Efficiency (CE)}

Coulombic efficiency didefinisikan sebagai rasio total Coulombs yang ditransfer ke anoda dari substrat dibagi dengan kemungkinan Coulombs maksimum yang dapat dihasilkan jika semua substrat disisihkan untuk menghasilkan listrik. Nilai CE diperoleh dari formula perhitungan yang menggunakan nilai penurunan COD. 
Parameter ini mengukur seberapa besar substrat (beban organik) yang mampu terolah dan terkonversi menjadi listrik (coulombic efficiency), biomassa (hasil pertumbuhan) dan melalui reaksi kompetitif dengan akseptor elektron alternatif (nitrat, oksigen, dan sulfat) (Logan et al, 2006).Grafik peningkatan dan penurunan $\mathrm{CE}$ dapat dilihat pada Gambar 3. Pada sampah daun dihasilkan CE tertinggi di hari ke-15 sebesar $0,486 \%$.Sampah makanan CE tertinggi di hari ke-5 sebesar 0,820\%.Sedangkan pada sampah campuran dihasilkan CE tertinggi di hari ke-15 sebesar 0,647\%.Nilai CE yang dihasilkan penelitian ini lebih rendah daripada hasil nilai CE penelitan Liu et al. (2005) sebesar 3-12 \% dengan substrat air limbah.Sedangkan CSMFCs hanya mengandalkan kadar air yang tersedia pada substrat untuk larut karena berupa padatan.Nilai CE yang rendah dapat juga terjadi karena densitas biofilm bakteri eksoelektrogen yang rendah akibat terjadinya kompetisi pertumbuhandengan komunitas mikrobalainpadapermukaan anoda (Lee et al., 2008).

\section{Energy Efficiency (EE)}

Nilai energy efficiency (EE) dapat dievaluasi dari proses transfer elektron pada MFCs. Nilai EE didapatkan dari jumlah daya listrik yang terukur dibagi dengan jumlah energi total yang didapatkan dari reaksi degradasi senyawa organik (Utami dkk., 2017). Pada sampah daun, EE tertinggi di hari ke-15 sebesar 0,0054\%. Sampah makanan, EE tertinggi pada hari ke-5 diperoleh sebesar $0,0254 \%$. Sedangkan pada sampah campuran, EE tertinggi terjadi di hari ke-15 sebesar 0,0127\%. Grafik peningkatan dan penurunan energy efficiency dapat dilihat pada Gambar 4. Kehilangan energi (energy losses) pada sistem dapat menyebabkan nilai EE yang rendah. Listrik dalam MFCs yang terukurakan lebih kecil daripadahasil energi listrik secara teoritis. Hal ini diakibatkan kehilangan potensial yang berhubungan dengan transfer elektron serta adanya hambatan internal (Sitorus, 2010 dalam Utami, dkk., 2017). Menurut Lee et al., (2008),komunitasmikroba eksoelektrogen cenderung menyukai produk fermentasi dari glukosa seperti asetat sehingga terdapat juga komunitasmikroba fermentatif. Hal ini dapat mengakibatkan lapisan biofilm menebal, namun didominasi biomassa non eksoelektrogen atau inert yang tidak dapat menghasilkan arus. Keadaaan ini dapat mengakibatkan konsentrasi elektron donor menurun dan laju transfer massa terhambat pada permukaan anoda sehingga nilai efisiensi energi rendah.

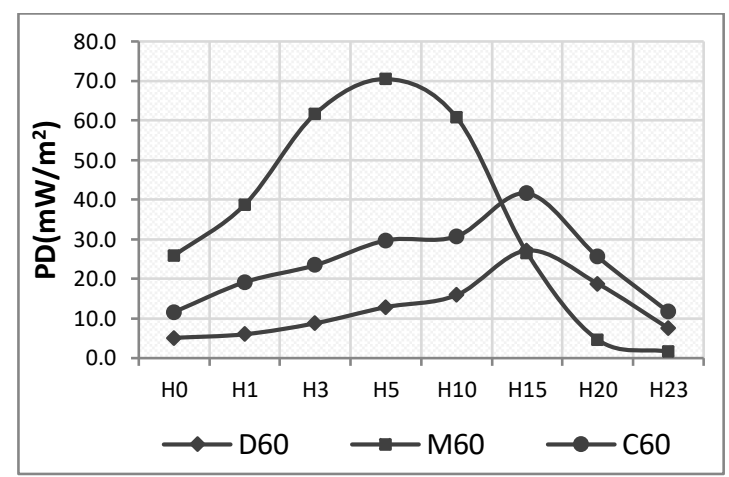

Gambar 2. Pengaruh Rasio Bahan Terhadap Produksi Listrik dalam Power Density

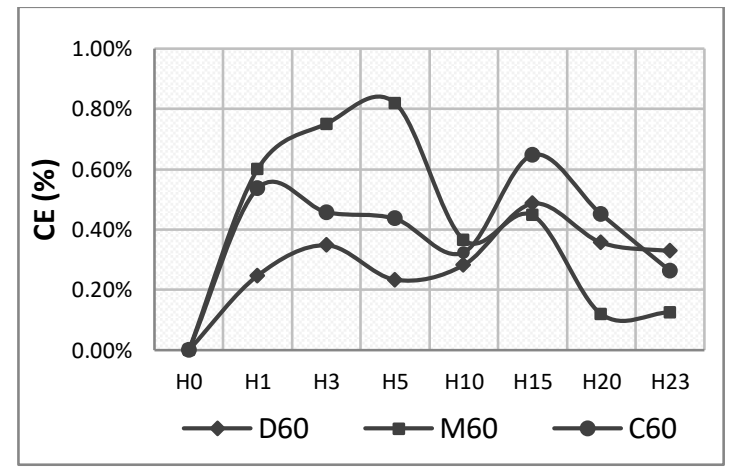

Gambar 3. Pengaruh Rasio Bahan Terhadap Produksi Listrikdalam Coulombic Efficiency

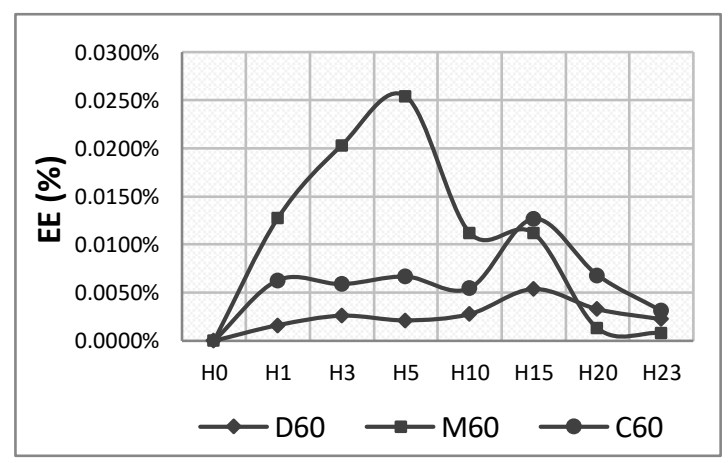

Gambar 4. Pengaruh Rasio Bahan Terhadap Produksi Listrik dalamEnergy Efficiency

\section{Kesimpulan}

Berdasarkan hasil penelitian, variasi bahan sampah memiliki pengaruh terhadap produksi kompos dan nilai produksi listrik yang dihasilkan. Semakin tinggi kadar nutrisi N, P, $\mathrm{K}$ pada bahan sampah awal yang digunakan, maka semakin banyak pula ketersediaan organik yang disuplai bagi bakteri sehingga dapat dikonversikan menjadi energi listrik. Variasi pada reaktor $\mathrm{C60}$ yang berisi bahan sampah campuran daun dan makanan dengan rasio 50:50 merupakan variasi yang paling optimum dalam kualitas kompos dan 
produksi listrik. Hasil tersebut diperoleh kualitas kompos yang baik, parameter kompos akhir telah memenuhi SNI 19-70302004 yaitu kadar C-Organik sebesar 15,83\%, $\mathrm{N}$-Total sebesar $0,99 \%$, rasio $\mathrm{C} / \mathrm{N}$ sebesar $15,92 \%$, P-Total sebesar 0,56\%, K-Total sebesar $2,08 \%$, pada suhu $27^{\circ} \mathrm{C}$ serta $\mathrm{pH}$ 6,9 . Selain itu, hasil produksi listrik diperoleh cukup tinggi, yaitunilai power density 41,6 $\mathrm{mW} / \mathrm{m}^{2}$, coulombic efficiency $0,647 \%$ dan energy efficiency0,0127\%.

Ucapan Terima Kasih: Ucapan terima kasih kepada Departemen Teknik Lingkungan dan Laboratorium Teknik Lingkungan Fakultas Teknik Universitas Diponegoro atas fasilitas yang diberikan selama penelitian.

\section{Daftar Pustaka}

Ayuningtias, Dyah Nurhati. (2009). Pengaruh Ketersediaan Oksigen dan Sistem Aerasi terhadap Laju Proses Pengomposan dan Kualitas Kompos Berbahan Baku Limbah Pencucian Biji Kakao Terfermentasi, Serasah Daun, dan Kotoran Sapi.Bogor : Institut Pertanian Bogor.

Bernal, M.P., J.A. Alburquerque, dan R. Moral. (2009). Composting of Animal Manures and Chemical Criteria for Compost Maturity Assesment. Departement of Soil and Water Conservation and Organic Waste Management. Murcia.

Jannah, Miftahul. (2003). Evaluasi Kualitas Kompos dari Berbagai Kota sebagai Dasar dalam Pembuatan SOP (Standar Operating Procedure) Pengomposan.Fakultas Teknik Pertanian Institut Pertanian Bogor. Bogor:

Kothapalli, Ananta. (2013). Sediment Microbial Fuel Cell as Sustainable Power Resource (Thesis and Dissertations).Paper 294.University of Wisconsin Milwaukee.

Kristin, Ester. (2012). Produksi Energi Listrik Melalui Microbial Fuel Cell Menggunakan Limbah Industri Tempe.Skripsi. Program Studi Teknologi Bioproses. Fakultas Teknik. Universitas Indonesia

Kusuma, M. Angga. (2012). Pengaruh Variasi Kadar Air Terhadap Laju Dekomposisi Kompos Sampah Organik di Kota Depok.(Tesis). Depok: Fakultas Teknik Program Studi Teknik Lingkugan Universitas Indonesia.
Lee, Hong S., Parameswaran, P. KatoMarcus, A. Torres, C.I. (2008). Evaluation of Energy-Conversion Efficiencies In Microbial Fuel Cells (MFCs) Utilizing Fermentable and Non-Fermentable Substrates. Water Research. 42(6-7): 1501-1510.

Liu, Hong., Cheng, Shaoan., and Logan, Bruce E. (2005). Production of Electricity from Acetate or Butyrate Using a Single-Chamber Microbial Fuel Cell. Environ. Sci. Technol. 2005, 39, 658-662.

Logan B. E., Hamelers, Bert., Rozendal, R., Schroder, U., Keller, J., Freguia, S., Aelterman, P., Verstraete, W., Rabaey, K. (2006). Microbial Fuel Cells: Methodology and Technology. Environmental Science \& Technology 40:5181-5192.

Logan, B. E. (2008). Microbial Fuel Cell. New Jersey: John Wiley \& Sons. 216 p.

Logroño, Washington., Ramirez, Geovany., Recalde, Celso., Echeverria, Magdy., dan Cunachi, Ana. (2015). Bioelectricity Generation From Vegetables and Fruits Wastes by Using Single Chamber Microbial Fuel Cells With High Andean Soils. Energy Procedia, Volume 75, August 2015, Pages 2009-2014.

Mulyani, Happy. 2014. Buku Ajar Kajian Teori dan Aplikasi : Optimasi Perancangan Model Pengomposan.Jakarta : CV. Trans Info Media.

Moqsud, M.A., Rahman, M.H., Hayashi, S., Du, Y.J., (2008). An Assessment of Modified Composting Barrel For Sustainable Organic Waste Management In Bangladesh. Journal of Solid Waste Technology and Management 34 (1), 35-46.

Samudro, Ganjar., Syafrudin., Nugraha, Winardi D., Sutrisno, Endro., Priyambada, Ika B., Muthi'ah, Hilma., Sinaga, Glory N., Hakiem, Rahmat T. (2017). The Effect of COD Concentration Containing Leaves Litter, Canteen and Composite Waste to the Performance of Solid Phase Microbial Fuel Cell (SMFC). E3S Web of Conferences 31, 02008 (2018) ICENIS 2017 : https://doi.org/10.1051/e3sconf/2018 3102008.

Setyorini, Diah., Saraswati, Rasti., Anwar, Ea Kosman.(2006). Pupuk Organik dan Pupuk Hayati. Pengaruh Rasio C/N Bahan Baku Pembuatan Kompos, 76. 
Sidabutar, Noni V. (2012). Peningkatan Kualitas Kompos UPS Permata Regency dengan Penambahan Kotoran Ayam Menggunakan Windrow Composting. Jakarta: Teknik Lingkungan Universitas Indonesia.

Siswanto, Thesa. (2012). Pengaruh Penambahan Bahan Berunsur Karbon Tinggi Untuk Meningkatkan Nilai Rasio C/N Pada Kompos di UPS.Depok : Fakultas Teknik Universitas Indonesia.

Standar Nasional Indonesia 19-7030-2004 Tentang Spesifikasi Kompos DariSampah Organik Domestik.

Suswardany, Dwi. L., Ambarawati., Kusumawati, Yuli.(2006). Peran Efective Mikroorganisme (EM-4) dalam Meningkatkan Kualitas Kimia Kompos Ampas Tahu. Jurnal Penelitian Sains dan Teknologi, Vol.7 No 2:141-149.

Utami, Tania S., Arbianti, Rita., Mulyana, Guruh M.(2017). Evaluasi Produksi Listrik Sumber Energi Terbarukan Sel Elektrokimia Berbasis Mikroba Pada Volume Reaktor Yang Berbeda. pISSN : 2407-1846. Website : jurnal.umj.ac.id/index.php/semnaste

Undang-Undang Republik Indonesia No. 18 Tahun 2018 Tentang Pengelolaan Sampah.

Wahyono, Sry., Sahwan, Firman L., Suryanto, Feddy.(2011). Membuat Pupuk Organik Granul dari Aneka Limbah.Jakarta : PT. AgroMedia Pustaka.

Walidaini, Rantidaista A., Nugraha, Winardi D., Samudro, Ganjar.(2016).
Pengaruh Penambahan Pupuk Urea dalam Pengomposan Sampah Organik secara Aerobik menjadi Kompos Matang dan Stabil. Semarang: Universitas Diponegoro.

Wang, et al. (2013).Electrical analysis Electrical Analysis of Compost Solid Phase Microbial Fuel Cell.International journal of hydrogen energy, 38(25), pp.1112411130.Taiwan: Hydrogen Energy Publications, LLC.

Wibawati, Riya.E. (2013).Rasio C/N, Kandungan Kalium (K), Keasaman (pH),dan Bau Kompos Hasil Pengomposan Sampah Organik Pasar dengan Starter Kotoran Sapi. Semarang: IKIP PGRI Semarang.

Widarti, Budi N., Wardhini, Wardah K., Sarwono, Edhi.(2015). Pengaruh Rasio C/N Bahan Baku pada Pembuatan Kompos dari Kubis dan Kulit Pisang. Jurnal Integrasi Proses, 75-80.

Yulianto, Agung., Zaman, Barus., Purwono.(2017). Pengaruh Penambahan Pupuk Organik Kotoran Sapi Terhadap Kualitas Kompos Dari Sampah Daun Kering di TPST Undip. Jurnal Teknik Lingkungan, Vol. 6, No. 3.

Yuan, H. dan He, Z., 2015.GrapheneModified Electrodes For Enhancing The Performance of Microbial Fuel Cells. Nanoscale, 7(16), pp.70227029. 